\title{
Development and Storage Studies of Aonla (Emblica officinalis Gaertn.) based Ready to Serve (RTS) Using Different Sweeteners
}

\author{
V. S. Meena ${ }^{1^{*}}$, P. C. Sharma ${ }^{2}$, V. S. Yadav ${ }^{3}$, R. S. Meena ${ }^{3}$, Manoj Mahawar ${ }^{4}$, Bharat Bhushan ${ }^{4}$, Kirti Jalgaonkar ${ }^{4}$, Pankaj \\ Kannaujia ${ }^{4}$ and K. K. Meena ${ }^{3}$ \\ ${ }^{1}$ ICAR- National Bureau of Plant Genetic Resources, NBPGR, New Delhi (110 012), India \\ ${ }^{2}$ College of Horticulture \& Forestry, Dr. Y.S.P.H. \& Forestry, Neri-Hamirpur, Himachal Pradesh (171 001), India \\ ${ }^{3}$ Rajasthan agricultural Research Institute, Durgapura, Jaipur, Rajasthan (302 015), India \\ ${ }^{4}$ ICAR-CIPHET, Abohar, Punjab (152 116), India
}

\section{Corresponding Author}

V. S. Meena

e-mail:vjy_meena@yahoo.com

\author{
Article History \\ Article ID: 3ICBSM0078 \\ Received in $7^{\text {th }}$ September, 2017 \\ Received in revised form $24^{\text {th }}$ November, 2017 \\ Accepted in final form $3^{\text {rd }}$ December, 2017
}

\begin{abstract}
The investigation on preparation of ready-to-serve beverage from Aonla using sugar substitutes was conducted at ICAR-CIPHET, Abohar (Punjab) during 2014-15. The experiment was laid out in completely randomised design with three replications and four treatments viz., sucrose, aspartame, sucralose and stevia with $50 \%$ juice made by blending of $60 \%$ of aonla, $20 \%$ pomegranate and $20 \%$ aloe vera. The RTS beverage with no sugar was the control. Sugar substitutes were used in place of sugar based on sugar equivalents. The required quantities of juice, sugar substitutes, water and citric acid were calculated. Strained fruit juice and freshly prepared sugar syrup were mixed together in the proportion as per the recipes on weight basis. The prepared RTS beverages were stored up to six months and analysed for chemical composition and sensory quality attributes sensory quality attributes at $0,30,60,90,120,150$ and 180 days intervals at ambient conditions. At the end of storage, RTS with stevia $4 \%$ was found best among all in term biochemical and sensory quality. During storage period, the TSS, acidity and total sugars increased, while $\mathrm{pH}$, and ascorbic acid decreased. The RTS beverage had storage stability up to six months. The developed RTS could be recommended for the large scale production at industrial level.
\end{abstract}

Keywords: Aonla juice, rts, sweeteners, storage, blending

\section{Introduction}

Aonla, the Indian gooseberry is recognized as the king of arid fruits. The fruit is highly nutritious and is a rich source of ascorbic acid and polyphenols. Aonla has been cultivated in India since time immemorial. It is an important fruit crop of semi-arid and arid regions and is grown commercially because of high economic return, therapeutic and nutraceutical value (Singh and Pathak, 1987). It is suitable for marginal lands and does not require much care (Singh et al., 2006). It is being grown across the country in an area of 108000 ha, producing 1266.46000 tonnes annually (NHB, 2013). Fruits of aonla are rich source of vitamins C (400-900 mg $\left.100 \mathrm{~g}^{-1}\right)$, pectins $\&$ tannins and are being used in various ayurvedic and unani systems of medicines (Gopalan et al., 1995). The fast increase in acreage and production may pose a serious problem for its disposal. Although, consumption of raw aonla fruit is considered to be good for human health, but because of the inherent high astringency it has little table value. Therefore, it can processed into various products viz. murabba, candy, juice, pickle, powder, segments-in-syrup etc. Among these, juice is the preferred product. The blended fruit beverages are far superior to synthetic beverages in terms of quality. They are easily digestible, highly refreshing, thirst-quenching, appetizing and nutritionally far superior than many synthetic and aerated drinks (Srivastava, 2004).

Presently, fruit juice consumption has increased substantially, probably due to public perception of fruit juices as a healthy natural source of nutrient. Blending of aonla juice with fruits like pomegranate, ber and oranges available during the season appear to be a viable approach to develop an acceptable aonla based drink. Therefore, blending of two or more fruit juices for the preparation of ready-to-serve beverage appears to be a convenient and economical alternative for utilization of aonla Sandhu and Sandhu (1992); Saxena et al. (1996); Attri et al. (1998) and Langthasa (1999).

It is quite evident that Indian is most sweet lovers. Sucrose has been single most important ingredient in the manufacture of all types of confectionary from simplest to sophisticated. Moreover, India is the largest producer and consumer of sucrose in the world. But, over the past few decades 
the nutritional role of sucrose has become the subject of controversy due to changing dietary needs of urbanized population (Nishad and Gowda, 2006). Medical, academic and industry associations have studied the involvement of sucrose in ailments such as dental, obesity, diabetes and heart diseases.

To meet requirement and demands for sugar free products, alternative sweeteners have come in to use. Sugar replacers are used in large variety of products. The discovery of large number of sweeteners over past a few decades has led to development of such type of products particularly for weight watcher or person prone to obesity. Presently, low calorie products in combination with low amount of sugar are gaining increasing acceptance to the consumers.

\subsection{Practical Application}

Presently due to awareness among urban and rural population that synthetic beverage contained the large amount of pesticides which causing heath hazards like allergy and stomach and even cancer like disease. Thus the population particularly metro cities population inclined towards consumption of fresh and processed juice of fruits crops. Juices have high demand in market but a particular juice is rich in particularly vitamins and mineral. Hence to provide a beverage having sufficient of vitamins and mineral could be developed by blending of fruit juices which are supposed to be far superior to synthetic beverages in terms of quality during the season. They are easily digestible, highly refreshing, thirst-quenching, appetizing and nutritionally far superior to many synthetic and aerated drinks.

Now a day's demand of Ready to serve (RTS) increasing at a high rate for consumption in all age of groups. Blended RTS beverage based on blends of aonla, pomegranate and aloe vera juice extracts receiving a considerable amount of attention reflecting a growing awareness of the potential of these products in the market place. Thus beverages have high nutritional quality and increased energy value especially therapeutic properties into the beverages. These could be particularly useful in place where there is lack of food and improper nutrition. Thus present study was carried out to investigate blending of seasonal juices together in combination of different sweeteners to biochemical and sensory acceptability of the juice product.

\section{Materials and Methods}

\subsection{Preparation of aonla based blended Rts}

The investigation on development for preparation of readyto-serve beverage from Aonla using sugar substitutes was conducted at ICAR- CIPHET, Abohar during 2014-15. The Abohar city, also known as California of India, is a south west part of Punjab state located at latitude $30.10^{\circ} \mathrm{N}$ and longitude $74.10^{\circ} \mathrm{E}$ and positioned at elevation of 179.8 meter above mean sea level. The experiment was conducted in completely randomized block design using sweeteners along with control.
Two artificial sweeteners viz. aspartame ( $\mathrm{Hi}$ media) and sucralose (Hi media) and one natural sweetener i.e., stevia (sunrise) used for replacing the sugar in prepared RTS. The fully matured, well-developed and uniform sized variety Chakaiya of aonla fruits and aloe vera leaf (Aloe barbendesis) and Mridula Cv. of pomegranate obtained from ICAR-CIPHET, Abohar orchard. Aonla fruit washed and shredded with the help of aonla shredder and passed through hydraulic press to extract juice. The extracted juice after filtration was stored at refrigerated condition until used in further experimentation. Selected aloe vera leaves were subjected for pre-processing (cut of tip and edge) then jel was extracted and finally juice was filtered and stored in refrigerator $\left(4 \pm 2{ }^{\circ} \mathrm{C}\right)$. The fully ripe fruits of pomegranate were cut into pieces and arils were separated. These arils were passed through the juicer for extraction of juice and the strained juice was kept in refrigerator for experimental use.

Equal amount of water in blended juice contained $60 \%$ of aonla, $20 \%$ pomegranate and $20 \%$ aloe vera juice was dissolved (1:1 ratio, v/v) and five percent sugar was kept uniformly in each treatment except control. The RTS beverage with no sugar was the control. Sugar substitutes were used in place of sugar based on sugar equivalents. The prepared RTS beverages filled into pre-sterilized glass bottles of $200 \mathrm{ml}$ capacity each. The bottles were then sealed with crown caps using hand operated crown corking machine and subjected for analysis of bio chemical and sensory quality attributes periodically at ambient condition.

\begin{tabular}{llc}
\hline \multicolumn{2}{l}{ Treatment detail } & \\
\hline Sl. No. & Treatment & Notation \\
\hline 1. & Control (Blended juice * with No sugar) & $\mathrm{T}_{1}$ \\
2. & Blended juice* with $5 \%$ sucrose & $\mathrm{T}_{2}$ \\
3. & Blended juice* with sucralose $10 \mathrm{ppm}$ & $\mathrm{T}_{3}$ \\
4. & Blended juice* with aspartame 10 ppm & $\mathrm{T}_{4}$ \\
5. & Blended juice * with stevia 4\% & $\mathrm{T}_{5}$ \\
\hline
\end{tabular}

*Blended juice: $60 \%$ of aonla, $20 \%$ pomegranate and $20 \%$ aloe vera

\subsection{Bio chemical analysis}

\subsubsection{Titratable acidity (\%)}

The titratable acidity was determined by the method suggested by A.O.A.C. (1980). Known volume of clear juice was diluted to 10 times with glass distilled water and titrated against standard $\mathrm{N} / 10 \mathrm{NaOH}$ solution using phenolphthalein as an indicator. The appearance of light pink colour was taken as the end point. The acidity of the juice was expressed in terms of per cent acidity as citric acid.

Titratable acidity $(\%)=(0.0064 \times$ Volume of $\mathrm{NaOH}$ used $) /$ (Volume of Sample taken) $\times 100$

\subsubsection{Ascorbic acid (mg $100 \mathrm{ml}^{-1}$ )}

The ascorbic acid content was determined by diluting known 
volume of juice with 3 per cent metaphosphoric acid as buffer and titrating it against 2,6-dichlorophenol-indophenol dye solution (A.O.A.C., 1980) until the stable faint pink colour was obtained. The results were expressed as $\mathrm{mg}$ of ascorbic acid per $100 \mathrm{ml}$ of fruit juice.

\subsubsection{Standardization:}

Standardization of 2,6-dichlorophenol indophenols dye solution was done against standard ascorbic acid solution. $100 \mathrm{mg}$ of pure L-ascorbic acid was dissolved in $3 \%$ metaphosphoric acid and volume was made upto $100 \mathrm{ml}$. One $\mathrm{ml}$ of ascorbic acid solution from this solution was used for titration. The results were expressed as $\mathrm{mg}$ of ascorbic acid per100 $\mathrm{ml}$ of fruit juice.

Ascorbic acid $\left(\mathrm{mg} 100 \mathrm{ml}^{-1}\right)=($ TitrexDye factor $\times$ Volume made up)/(Aliquot $\times$ weight or volume taken $) \times 100$

\subsection{3. $\mathrm{pH}$}

The $\mathrm{pH}$ of the juice was directly determined by a $\mathrm{pH}$ meter (Systronics) after standardization with a buffer ( $\mathrm{pH} 4.0)$.

\subsubsection{Total sugars (\%)}

Total Sugars content was determined by using anthrone reagent method (Dubois et al., 1951). To $1 \mathrm{ml}$ of diluted fruit juices (1000 times diluted), $4 \mathrm{ml}$ of anthrone reagent was added, heated for 10 to 15 minutes in a water bath, cooled to room temperature and absorbance was measured at 630 $\mathrm{nm}$ on spectrophotometer.

The amount of sugars present in the juice was plotted against standard curve which was prepared from standard glucose solution. The content was expressed on percentage basis.

\subsubsection{Organoleptic evaluation}

The blended beverages were evaluated for sensory qualities on the basis of colour (appearance), taste and aroma, palatability and overall acceptability by a panel of 10 judges on a 9 - point Hedonic scale (Amerine et al., 1965)

\subsubsection{Statistical analysis}

Data were analysed statistically using completely block design (CRD). The analyses of variance for different characters are presented in tables were assessed. The critical difference at $5 \%$ was calculated to assess the significance of differences between the treatments.

\section{Results and Discussion}

Changes in chemical composition of sweet orange RTS beverage with sugar substitutes

\subsection{Titratable acidity}

Titratable acidity was maximum in RTS with sucralose at initial time which increased in all treatment. (Table 1). Increase in titratable acidity during storage could be due to release of acids from the juice by autolysis. Similar results were obtained by Sogi and Singh (2001) in kinnow RTS, Choudhary et al. (2006) in guava RTS and Kumar (1990) in papaya beverage.
Table 1: Changes in acidity (\%) of aonla base blended RTS during storage

\begin{tabular}{lccccccc}
\hline $\begin{array}{l}\text { Treat- } \\
\text { ments }\end{array}$ & $\begin{array}{c}0 \\
\text { days }\end{array}$ & $\begin{array}{c}30 \\
\text { days }\end{array}$ & $\begin{array}{c}60 \\
\text { days }\end{array}$ & $\begin{array}{c}90 \\
\text { days }\end{array}$ & $\begin{array}{c}120 \\
\text { days }\end{array}$ & $\begin{array}{c}150 \\
\text { days }\end{array}$ & $\begin{array}{c}180 \\
\text { days }\end{array}$ \\
\hline $\mathrm{T}_{1}$ & 0.35 & 0.37 & 0.38 & 0.38 & 0.40 & 0.41 & 0.42 \\
$\mathrm{~T}_{2}$ & 0.35 & 0.37 & 0.38 & 0.39 & 0.43 & 0.44 & 0.47 \\
$\mathrm{~T}_{3}$ & 0.42 & 0.42 & 0.42 & 0.43 & 0.48 & 0.52 & 0.52 \\
$\mathrm{~T}_{4}$ & 0.40 & 0.45 & 0.45 & 0.46 & 0.50 & 0.51 & 0.52 \\
$\mathrm{~T}_{5}$ & 0.39 & 0.40 & 0.43 & 0.44 & 0.50 & 0.52 & 0.54 \\
$\mathrm{SEm} \pm$ & $\mathrm{NS}$ & $\mathrm{NS}$ & $\mathrm{NS}$ & $\mathrm{NS}$ & $\mathrm{NS}$ & $\mathrm{NS}$ & $\mathrm{NS}$ \\
$\mathrm{CD}$ & $\mathrm{NS}$ & $\mathrm{NS}$ & $\mathrm{NS}$ & $\mathrm{NS}$ & $\mathrm{NS}$ & $\mathrm{NS}$ & $\mathrm{NS}$ \\
$(p=0.05)$ & & & & & & & \\
\hline
\end{tabular}

The results pertaining to the increase in acidity and decrease in $\mathrm{pH}$ during storage of aonla blended juice are in complete agreement with other researchers Doreyapa and Jalali (1995). The increase in acidity may be ascribed to rise in the concentration of weakly ionized acid and their salts during storage. This increase in acidity might also be due to formation of acid by degradation of polysaccharides and oxidation of reducing sugars or by breakdown of peptic substances and uronic acid same reported by Hussain et al. (2011).

\subsection{Total sugars}

Significantly higher total sugars were observed in RTS with sucrose, while RTS with stevia had least total sugars (Table 2). Higher total sugars in RTS beverage were due to addition of sucrose (sugar) at the time of preparation. Sucralose, being a sugar substitute, has no sugars and recorded least total sugars. Increase in total sugars in RTS beverage with sugar substitutes

Table 2: Changes in total sugar (\%) of aonla base blended RTS during storage

\begin{tabular}{lccccccc}
\hline $\begin{array}{l}\text { Treat- } \\
\text { ments }\end{array}$ & $\begin{array}{c}0 \\
\text { days }\end{array}$ & $\begin{array}{c}30 \\
\text { days }\end{array}$ & $\begin{array}{c}60 \\
\text { days }\end{array}$ & $\begin{array}{c}90 \\
\text { days }\end{array}$ & $\begin{array}{c}120 \\
\text { days }\end{array}$ & $\begin{array}{c}150 \\
\text { days }\end{array}$ & $\begin{array}{c}180 \\
\text { days }\end{array}$ \\
\hline $\mathrm{T}_{1}$ & 4.00 & 4.03 & 4.08 & 4.12 & 4.12 & 4.15 & 4.17 \\
$\mathrm{~T}_{2}$ & 8.87 & 8.93 & 8.97 & 9.00 & 9.03 & 9.03 & 9.07 \\
$\mathrm{~T}_{3}$ & 8.83 & 8.87 & 8.90 & 8.93 & 8.97 & 9.00 & 9.03 \\
$\mathrm{~T}_{4}$ & 8.73 & 8.77 & 8.78 & 8.80 & 8.83 & 8.87 & 8.90 \\
$\mathrm{~T}_{5}$ & 8.67 & 8.70 & 8.73 & 8.77 & 8.80 & 8.83 & 8.87 \\
$\mathrm{SEm} \pm$ & 0.25 & 0.21 & 0.19 & 0.19 & 0.18 & 0.16 & 0.15 \\
$\mathrm{CD}$ & 0.58 & 0.45 & 0.40 & 0.41 & 0.38 & 0.34 & 0.32 \\
$(p=0.05)$ & & & & & & & \\
\hline
\end{tabular}

might be attributed to kum syrup, Sashikumar et al. (2013) in aonla blended RTS and Yadav the reactions of sugars with amino acids. Similar trend of increase in sugars have been reported by Waskar and Khurdiya (1987) in phalsa syrup, Jadhav et al. (2006) in Ko et al. (2014) on carrot juice blends. 


\subsection{Ascorbic acid}

Significantly higher ascorbic acid was found in aonla based RTS at initial time of storage which leads to decease as the storage period advanced (Table 3 ). Sweeteners did not affected ascorbic acid significantly during storage. It is well known that ascorbic acid is most labile vitamin in all and very sensitive to oxidation and light. Various factors affect ascorbic acid degradation such as oxygen, heat, light and storage. Degradation of ascorbic acid proceeds in both conditions in presence and absence of oxygen (Johnson et al., 1995). The presence of air at the headspace of glass bottles of RTS during storage is one of the most important reasons for its degradation (Huelin, 1953). This might be due to oxidation

Table 3: Changes in Ascorbic acid (mg $100 \mathrm{~g}^{-1}$ ) of aonla base blended RTS during storage

\begin{tabular}{lccccccc}
\hline $\begin{array}{l}\text { Treat- } \\
\text { ments }\end{array}$ & 0 days & $\begin{array}{c}30 \\
\text { days }\end{array}$ & $\begin{array}{c}60 \\
\text { days }\end{array}$ & $\begin{array}{c}90 \\
\text { days }\end{array}$ & $\begin{array}{c}120 \\
\text { days }\end{array}$ & $\begin{array}{c}150 \\
\text { days }\end{array}$ & $\begin{array}{c}180 \\
\text { days }\end{array}$ \\
\hline $\mathrm{T}_{1}$ & 110.00 & 105.67 & 91.00 & 88.33 & 75.00 & 70.00 & 66.67 \\
$\mathrm{~T}_{2}$ & 109.00 & 107.00 & 94.33 & 87.67 & 76.67 & 74.33 & 71.67 \\
$\mathrm{~T}_{3}$ & 110.00 & 106.00 & 93.33 & 87.67 & 76.67 & 71.67 & 70.00 \\
$\mathrm{~T}_{4}$ & 110.67 & 106.67 & 94.00 & 84.33 & 77.00 & 76.00 & 72.67 \\
$\mathrm{~T}_{5}$ & 110.67 & 106.67 & 94.67 & 85.00 & 77.33 & 74.67 & 71.00 \\
SEm \pm & NS & NS & NS & NS & NS & NS & NS \\
CD & NS & NS & NS & NS & NS & NS & NS \\
\hline
\end{tabular}

$\mathrm{CD}(p=0.05)$

of entrapped oxygen in glass bottles and its degradation to dehydro ascorbic acid, furfural and hydroxyl furfural during NEB process and thermal degradation. Analogue results have been reported Nishad and Gowda (2006) in lime beverage.

Similar results also noticed by various workers including Bhardwaj and Mukherjee (2011) on kinnow, Yadav et al. (2014) on carrot and fruit juices blend and Mehta and Bajaj (1983) in citrus juices.

\section{4. $\mathrm{pH}$}

$\mathrm{pH}$ plays dual role in the fruit juices by acting as a flavour promoter. $\mathrm{pH}$ was not affected significantly with the application of sweeteners (Table 4). However, storage of aonla based blended RTS beverage resulted in reduction of $\mathrm{pH}$ due to simultaneous increase in titratable acidity. Similar findings have been reported by Sogi and Singh (2001) in kinnow RTS beverage and Choudhary et al. (2006) in guava RTS beverage.

\subsection{Total soluble solids (TSS)}

Retention or minimum increase in total soluble solids content of juice during storage is desirable for preservation of good juice quality. The total soluble solids of juice combination with different proportions of juices and their further developed RTS beverage using artificial and natural sweeteners shows increased TSS with gradual passage of storage time. Highest
Table 4: Changes in $\mathrm{pH}$ of aonla base blended RTS during storage

\begin{tabular}{lccccccc}
\hline $\begin{array}{l}\text { Treat- } \\
\text { ments }\end{array}$ & $\begin{array}{c}0 \\
\text { days }\end{array}$ & $\begin{array}{c}30 \\
\text { days }\end{array}$ & $\begin{array}{c}60 \\
\text { days }\end{array}$ & $\begin{array}{c}90 \\
\text { days }\end{array}$ & $\begin{array}{c}120 \\
\text { days }\end{array}$ & $\begin{array}{c}150 \\
\text { days }\end{array}$ & $\begin{array}{c}180 \\
\text { days }\end{array}$ \\
\hline $\mathrm{T}_{1}$ & 3.28 & 3.20 & 3.13 & 3.07 & 3.03 & 3.00 & 2.97 \\
$\mathrm{~T}_{2}$ & 3.28 & 3.13 & 3.10 & 3.07 & 3.03 & 3.00 & 2.93 \\
$\mathrm{~T}_{3}$ & 3.23 & 3.10 & 3.07 & 3.03 & 3.00 & 2.97 & 2.93 \\
$\mathrm{~T}_{4}$ & 3.23 & 3.10 & 3.07 & 3.03 & 3.00 & 2.96 & 2.89 \\
$\mathrm{~T}_{5}$ & 3.26 & 3.17 & 3.12 & 3.07 & 3.03 & 3.00 & 2.83 \\
$\mathrm{SEm} \pm$ & $\mathrm{NS}$ & $\mathrm{NS}$ & $\mathrm{NS}$ & $\mathrm{NS}$ & $\mathrm{NS}$ & $\mathrm{NS}$ & $\mathrm{NS}$ \\
$\mathrm{CD}$ & $\mathrm{NS}$ & $\mathrm{NS}$ & $\mathrm{NS}$ & $\mathrm{NS}$ & $\mathrm{NS}$ & $\mathrm{NS}$ & $\mathrm{NS}$ \\
$(p=0.05)$ & & & & & & & \\
\hline
\end{tabular}

TSS content was recorded under T5 (13.0) at initial day of observation as well as till end of storage (12.73) compared to all other treatments. Perusal of data in Table 5 reveals a significant difference in TSS of different recipes. Highest TSS was found in stevia incorporated RTS followed by RTS with aspartame. TSS content was significantly increased with advancement of storage. However stevia incorporated blended RTS shown decreased TSS content as the storage time advanced. Similar trend of increase in total soluble solids with advancement of storage period were observed in kinnow juice by Bhardwaj and Mukherjee (2011). However, the rate of increase was more at ambient temperature as compared to refrigerated storage. Another possible reason for the rapid increment in soluble solid contents may be due to hydrolysis of sucrose to invert sugars. Similar findings have been reported by Ram et al. (2011) in in aonla and bael blended RTS beverage.

Table 5: Changes in TSS (O Brix) of aonla base blended RTS during storage

\begin{tabular}{lccccccc}
\hline $\begin{array}{l}\text { Treat- } \\
\text { ments }\end{array}$ & $\begin{array}{c}0 \\
\text { days }\end{array}$ & $\begin{array}{c}30 \\
\text { days }\end{array}$ & $\begin{array}{c}60 \\
\text { days }\end{array}$ & $\begin{array}{c}90 \\
\text { days }\end{array}$ & $\begin{array}{c}120 \\
\text { days }\end{array}$ & $\begin{array}{c}150 \\
\text { days }\end{array}$ & $\begin{array}{c}180 \\
\text { days }\end{array}$ \\
\hline $\mathrm{T}_{1}$ & 5.00 & 5.57 & 5.89 & 6.30 & 6.33 & 6.37 & 6.40 \\
$\mathrm{~T}_{2}$ & 10.00 & 11.07 & 11.13 & 11.20 & 11.27 & 11.30 & 11.33 \\
$\mathrm{~T}_{3}$ & 10.03 & 10.50 & 10.60 & 10.67 & 10.73 & 10.83 & 10.90 \\
$\mathrm{~T}_{4}$ & 10.07 & 10.33 & 10.43 & 10.50 & 10.60 & 10.63 & 10.67 \\
$\mathrm{~T}_{5}$ & 13.00 & 12.43 & 12.50 & 12.63 & 12.67 & 12.70 & 12.73 \\
$\mathrm{SEm} \pm$ & 0.43 & 0.47 & 0.46 & 0.46 & 0.43 & 0.40 & 0.38 \\
$\mathrm{CD}$ & 0.91 & 0.99 & 0.97 & 0.97 & 0.92 & 0.85 & 0.80 \\
\hline $\mathrm{CD}(p=0.05)$ & & & & & &
\end{tabular}

3.6. Organoleptic qualities of RTS beverage with sugar substitutes

The changes in organoleptic scores of aonla base blended RTS due to different sweeteners application was significantly Table 6. Highest overall acceptability score was found in RTS with stevia. Overall acceptability scores decreased during 
Table 6: Changes in overall sensory of aonla base blended RTS during storage

\begin{tabular}{lccccccc}
\hline $\begin{array}{l}\text { Treat- } \\
\text { ments }\end{array}$ & $\begin{array}{c}0 \\
\text { days }\end{array}$ & $\begin{array}{c}30 \\
\text { days }\end{array}$ & $\begin{array}{c}60 \\
\text { days }\end{array}$ & $\begin{array}{c}90 \\
\text { days }\end{array}$ & $\begin{array}{c}120 \\
\text { days }\end{array}$ & $\begin{array}{c}150 \\
\text { days }\end{array}$ & $\begin{array}{c}180 \\
\text { days }\end{array}$ \\
\hline $\mathrm{T}_{1}$ & 5.00 & 5.00 & 4.87 & 4.67 & 4.60 & 4.57 & 4.47 \\
$\mathrm{~T}_{2}$ & 7.00 & 6.93 & 6.73 & 6.67 & 6.57 & 6.17 & 6.07 \\
$\mathrm{~T}_{3}$ & 6.33 & 6.27 & 6.20 & 6.10 & 6.00 & 6.00 & 5.97 \\
$\mathrm{~T}_{4}$ & 6.33 & 6.17 & 6.03 & 6.00 & 5.93 & 5.93 & 5.83 \\
$\mathrm{~T}_{5}$ & 8.00 & 7.83 & 7.77 & 7.60 & 7.50 & 7.33 & 7.00 \\
$\mathrm{SEm} \pm$ & 0.46 & 0.56 & 0.42 & 0.29 & 0.26 & 0.27 & $\mathrm{NS}$ \\
$\mathrm{CD}$ & 0.96 & 1.18 & 0.88 & 0.61 & 0.56 & 0.57 & $\mathrm{NS}$ \\
$(p=0.05)$ & & & & & & & \\
\hline
\end{tabular}

storage. This might be due to decline in colour, consistency and flavour scores. These finding are in concurrence of with finding of multifruit RTS beverage by Sandu and Sindhu (1992) kinnow based blended beverage by Bhardwaj and Mukherjee (2011); apple pulp by Langthasa (1999) and aonla based juice by Sasikumar et al. (2013) have reported that two or more fruit juices/pulp blending in various proportions result in degraded organoleptic qualities of the beverages like RTS during storage.

\section{Conclusion}

In the present investigation, attempts have been made to prepare and standardize the method for Aonla-based sugar substitute beverage. The nutritious and functional beverages with better storage life have been developed by addition of stevia. RTS with stevia $4 \%$ rated superior in terms of biochemical properties, over all acceptability and taste and thus rated as best recipes.

\section{Future Research Needs}

In this research trial a method developed to support utilization of another seasonal fruits for doubling the farmers/ small scale processor income at their farm level. Development of such method found important for two reasons: first, the ever increasing competition, diversification of product and high level of service. Secondly this paper support to design process of sugar frees fruit juice blending and packaging plant. The growing awareness about aonla medicinal and nutritional value may be prove an alternative medicine, health foods and herbal products in future. As aonla fruit highly rich in vitamin $\mathrm{C}$ and tannins it has immense scope for processing industry. Value addition of this fruit in form the form of blended beverage could be boon for small scale orchardists or processors. However development of such beverages still needs to develop with another seasonal fruits and medicinal crop to improve its quality aspects.

\section{Acknowledgement}

Authors are thankful to Director, ICAR-CIPHET, Ludhiana,
India for providing necessary facility for carrying out the experiment.

\section{References}

Amerine, M.A., Pangborn, R.M., Rocssler, E.A., 1965. Principles of sensory evaluation of food. In: Food Science and Technology Monographs. Academic Press, London, 338-339.

Bhardwaj, R.L., Mukherjee, S., 2011. Effects of fruit juice blending ratios on kinnow juice preservation at ambient storage condition. African Journal of Food Science 5, 281-286.

Choudhary, M.L. Dikshit, S.N., Sharma, H.G., 2006. Studies on preparation and biochemical changes in guava RTS beverage during storage. Indian Journal of Arid Horticulture 1, 78-79.

Dubois, M., Gilies, K., Hammilton, J.K., Robers, P.A., Smith, F.A., 1951. A colorimetric method for the determination of sugars related substances. Analytical Chemistry 28, 350-356.

Gopalan, C., Ramasastri, B.V., Balasubramaninan, S.C., 1995. Nutritive value of Indian foods. National Institute of Nutrition, ICMR, Hyderabad, India, 45-94.

Huelin, F.E., 1953. Studies on the anaerobic decomposition of ascorbic acid. Food Research 18, 633-639.

Hussain, I., Zeb, A., Ayub, M., 2011. Evaluation of apple and apricot blend juice preserved with sodium benzoate at refrigeration temperature. World Journal of Agricultural Sciences 7(2), 136-142.

Jadhav, SB., Joshi, G.D., Garande, V.K., 2006. Studies on preparation and storage of raw and ripe kokum fruit products. Journal of Asian Horticulture 2(3), 205-207.

Johnson, J.R., Braddock, R.J., Chen, C.S., 1995. Kinetics of ascorbic acid loss and non enzymatic browning in orange juice serum: Experimental rate constants. Journal of Food Science 60(3), 502-505.

Langthasa, S., 1999. Processing and preservation of apple pulp. Ph.D Thesis, Indian Agricultural Research Institute, New Delhi, India.

Mehta, U., Bajaj, S., 1983. Effect of storage and method of preservation on physico-chemical characteristics of citrus juices. Indian Food Packer 37, 42-51.

NHB, 2013. All-India area and production of Fruits and vegetables. Indian Horticulture Database 2013, National Horticultural Board, Ministry of Agriculture, Government of India.

Nishad, Gowda, I.N.D., 2006. Studies on beverage preparation from lime fruit with alternative sweeteners. M.Sc. thesis, Mahatma Gandhi University, Kottayam, Kerala.

Ram, R.B., Meena, M.L., Sonkar, P., Lata, R., Upadhyay, A.K., 2011. Standardization and evaluation of blended aonla (Emblica officinalis Gaertn.) and bael (Aegle marmelos Correa) RTS beverages. Plant Archive 11, 205-208.

Sandhu, K.S., Sindhu, J.S., 1992. Studies on the development 
of multi fruits ready-to-serve beverage. Journal of Plant Science Research 8, 87-88.

Sasikumar, R., Ramesh, C., Ray, P., Paul, K., Suresh, C.P., 2013. Development and storage studies of therapeutic RTS made from blend of aloe vera, aonla and ginger juice. Journal of Food Processing Technology 4, 6-7.

Saxena, A.K. Teotia, M.S., Berry, S.K., 1996. Studies on the development of grape-mango and grape-pineapple beverage blends. Indian Food Packer 50, 26-29.

Singh, I.S., Pathak, R.K., 1987. Evaluation of amla varieties for processing. Acta Horticulture 208, 173-177.

Singh, S., Singh, A.K., Joshi, H.K., 2006. Standardization of maturity indices in Indian gooseberry (Emblica officinalis Gaertn) under semi-arid conditions of Gujarat. Indian Journal of Agricultural Sciences 76, 591-595.
Sogi, D.S., Singh, S., 2001. Studies on bitterness developmentin kinnow juice, ready to serve beverage, squash, jam and candy. Journal of Food Science and Technology 38(5), 433-438

Srivastava, R.P., Kumar, S., 2004. Fruit and Vegetable Preservation (Principle and Practices), International Book Distributing Company, Charbagh, Lucknow.

Waskar, D.P., Khurdiya, D.S., 1987. Effect of packaging containers on the anthocyanin of phalsa syrup. Indian Food Packer 41(5), 17-23.

Yadav, T.V., Choudhary, M.R., Garhwal, O.P., Mahala, P., Ujjainiya, P., 2014. Influence of heat processing on nutritional, physico-chemical and microbial quality of carrot-fruit juice blends. Annals of Biology 30(4), 711-720. 